\title{
Survey on the use of alternative and complementary medicine in Mexican patients with cancer in an oncology reference center
}

\author{
Mariana Navarro-Hernández¹, Nancy Reynoso-Noverón² and Amanda De la Piedra-Gómez ${ }^{1 *}$ \\ ${ }^{1}$ Integrative Oncology Center; ${ }^{2}$ Research Head Office. Instituto Nacional de Cancerología, Ciudad de México, Mexico
}

\begin{abstract}
Objective: To describe the frequency of use of alternative and complementary medicine (CAM) and its relationship with sociodemographic, economic and clinical variables in oncology patients treated at the National Cancer Institute. Material and methods: A structured and validated survey for a certain sociodemographic population was applied to measure the use of CAM. Results: We included 492 patients with breast, cervix and lung cancer mainly, $76.6 \%$ were women. The main diagnosis was breast cancer (37.4\%). Exercise, dietary supplements and herbal products were reported in $80 \%$; higher frequency in women aged 51-66 years and with more than four years diagnosis. Schooling and the type of neoplasia were associated with the use of these therapies. Conclusions: The use of CAM is common in oncologist patients. It is necessary to identify them in order to guide their use and consider them in the integral management of cancer.
\end{abstract}

Key words: Cancer. Integrative Oncology. Alternative medicine. Complementary therapies.

\section{Correspondence:}

*Amanda de la Piedra-Gómez

E-mail: amandadpg@ hotmail.com
Date of reception: 06-07-2018

Date of acceptance: $24-12-2018$

DOI: 10.24875/j.gamo.M19000173
Available online: 30-05-2019 Gac Mex Oncol. 2018;17:71-77 www.gamo-smeo.com 1665-9201/@ 2018 Sociedad Mexicana de Oncología. Published by Permanyer México. This is an Open Access article under the terms of the CC BY-NC-ND license (http://creativecommons.org/licenses/by-nc-nd/4.0/). 


\section{Introduction}

Cancer is one of the leading causes of disease and death in the world. In 2012, there were 14 million new cases and 8.2 million deaths related to this pathology ${ }^{1}$. It has been estimated that the number of new cases will increase by approximately $70 \%$ in the next 20 years $^{2}$. In Mexico, nearly 150,000 cases of cancer are detected every year and it is the second cause of death in the general population ${ }^{3}$. According to Gómez-Dantés et al., in Mexico there were 84,172 cancer deaths recorded in 2013 , out of which 41,281 (49\%) correspond to the male and $42,891(51 \%)$ to the female gender. The main causes of death in men were prostate and lung cancer $(6,296$ and 4,276 deaths, respectively). In the case of women, it was breast $(5,997$ deaths), cervical $(4,076)$ and liver and intrahepatic bile duct cancer $(3,124)^{4}$. This group of chronic diseases is associated with a high physical, societal and economic cost ${ }^{5}$. Currently, there are many types of conventional treatments for cancer and their indication depends on the type of oncological condition and the clinical stage it is at. However, in many cases, the results are not entirely positive for the patient, treatments cause serious side effects and disease control is not achieved ${ }^{6}$.

For this reason, many patients choose to combine the use complementary and alternative medicine (CAM), a term used to designate those products and medical practices that are considered not to belong to conventional medical care. Complementary medicine is used together with conventional medical treatments and alternative medicine is used instead of the usual treatment?

According to the World Health Organization, the terms complementary/alternative medicine are interchangeably used together with traditional medicine in some countries and refer to a wide array of health care practices that are not part of a country's own tradition and are not integrated into the social security healthcare and medical system $^{8}$. CAM encompasses a wide variety of therapies and practices and has been used for thousands of years ${ }^{9}$. The resurgence of its use in many developed and developing countries has occurred since the last decade of the twentieth century and it has been recognized as part of the care and support of patients with chronic-degenerative diseases ${ }^{10-12}$. In this sense, integrative oncology emphasizes on awareness and sensitivity regarding the mental, emotional and spiritual needs of the patient ${ }^{11}$. In Mexico, for social and cultural reasons, the use of traditional medicine, herbal medicine and home remedies of indefinite origin is quite common ${ }^{12,13}$.

The purpose of this study was to analyze the type and frequency of consumption of these treatments in cancer patients who attend the National Cancer Institute (INCan) to receive medical care, as well as their possible association with patients' sociodemographic and clinical profile.

\section{Material and methods}

To collect data on the use of CAM, a cross-sectional study was carried out with application of a questionnaire that was developed based on the Society for Integrative Oncology guidelines, which took into consideration various alternative and complementary treatment practices $^{14}$. This questionnaire was applied from January to March 2011 to 500 INCan patients who were recruited in waiting rooms. All recruited subjects had the capability to understand the language of the questionnaire, were in conditions to complete it by themselves and voluntarily agreed to participate in the study.

For data analysis, measures of central tendency and dispersion were calculated. Differences between the gender, diagnostic, socioeconomic and demographic variables and the use of CAM were assessed using the chi-square test $\left(\chi^{2}\right)$ or Fisher's exact test. Variables that might influence on the use of CAM were included in a multiple logistic regression model; this model was adjusted for gender, age, time since diagnosis, level of education and diagnosis, using the Stata/SE ${ }^{\circledR}$ software, version 12.

\section{Results}

\section{Sociodemographic and socioeconomic characteristics}

Five-hundred patients participated in the study, 398 were women $(76.6 \%)$ and had an average age of 51.36 $( \pm 12.85)$ years, and 94 were men $(18.8 \%)$, with a mean age of 53 ( \pm 16.34 ) years; eight subjects (1.6\%) did not specify their gender, and were therefore excluded from the study. The results herein presented correspond to 492 participants.

With regard to the level of education, $59 \%$ of patients had mainly a basic level (primary or secondary), 16\% had completed higher or postgraduate education, 15\% mentioned having completed high school education, $6 \%$ were people without formal education and $3 \%$ did not specify their level of education (Table 1). For affiliation, only having people's insurance or not was considered; $35 \%$ of participants were affiliated to said protection system, with $42 \%$ of women being affiliated in comparison with only $9 \%$ of men. 
Table 1. Sociodemographic, economic and clinical characteristics of the study population

\begin{tabular}{|c|c|c|c|c|c|}
\hline & \multicolumn{2}{|c|}{ Men } & \multicolumn{2}{|c|}{ Women } & \multirow[t]{2}{*}{$\mathbf{p}<\mathbf{Z}$} \\
\hline & No. of subjects & $\%$ & No. of subjects & $\%$ & \\
\hline Gender & 94 & 19.11 & 398 & 80.89 & \\
\hline $\begin{array}{l}\text { Level of education } \\
\text { Illiterate } \\
\text { Primary school } \\
\text { Secondary school } \\
\text { High school } \\
\text { College degree } \\
\text { Postgraduate } \\
\text { Not specified }\end{array}$ & $\begin{array}{c}8 \\
19 \\
28 \\
18 \\
11 \\
5 \\
5\end{array}$ & $\begin{array}{c}8.51 \\
20.21 \\
29.79 \\
19.15 \\
11.70 \\
5.32 \\
5.32\end{array}$ & $\begin{array}{c}22 \\
138 \\
107 \\
57 \\
57 \\
6 \\
11\end{array}$ & $\begin{array}{c}5.53 \\
34.67 \\
26.88 \\
14.32 \\
14.32 \\
1.51 \\
2.76\end{array}$ & 0.026 \\
\hline $\begin{array}{l}\text { Affiliation } \\
\text { People's insurance } \\
\text { No people's insurance } \\
\text { Not specified }\end{array}$ & $\begin{array}{c}8 \\
72 \\
14\end{array}$ & $\begin{array}{c}8.5 \\
76.6 \\
14.9\end{array}$ & $\begin{array}{c}166 \\
206 \\
26\end{array}$ & $\begin{array}{c}41.71 \\
51.76 \\
6.53\end{array}$ & 0.000 \\
\hline $\begin{array}{l}\text { Time elapsed since diagnosis } \\
\text { less than } 1 \text { year } \\
1 \text { year } \\
2 \text { years } \\
3 \text { years } \\
4 \text { years } \\
\text { more than } 5 \text { years } \\
\text { Not specified }\end{array}$ & $\begin{array}{c}32 \\
24 \\
14 \\
10 \\
1 \\
13 \\
0\end{array}$ & $\begin{array}{c}34.0 \\
25.5 \\
14.9 \\
10.6 \\
1.1 \\
13.8 \\
0.0\end{array}$ & $\begin{array}{l}127 \\
140 \\
33 \\
22 \\
16 \\
47 \\
13\end{array}$ & $\begin{array}{c}31.91 \\
35.18 \\
8.29 \\
5.53 \\
4.02 \\
11.81 \\
3.27\end{array}$ & 0.029 \\
\hline $\begin{array}{l}\text { Age by categories (years) } \\
\text { younger than } 34 \\
35 \text { to } 50 \\
51 \text { to } 66 \\
\text { older than } 67\end{array}$ & $\begin{array}{l}13 \\
27 \\
31 \\
23\end{array}$ & $\begin{array}{l}13.83 \\
28.72 \\
32.98 \\
24.47\end{array}$ & $\begin{array}{c}35 \\
156 \\
149 \\
58\end{array}$ & $\begin{array}{c}8.79 \\
39.2 \\
37.44 \\
14.57\end{array}$ & 0.027 \\
\hline $\begin{array}{l}\text { State of origin } \\
\text { Mexico City } \\
\text { State of Mexico } \\
\text { Hidalgo } \\
\text { Morelos } \\
\text { Tlaxcala } \\
\text { Other }\end{array}$ & $\begin{array}{c}26 \\
20 \\
9 \\
9 \\
4 \\
26\end{array}$ & $\begin{array}{c}27.66 \\
21.28 \\
9.57 \\
9.57 \\
4.26 \\
27.66\end{array}$ & $\begin{array}{l}139 \\
84 \\
35 \\
28 \\
16 \\
96\end{array}$ & $\begin{array}{c}34.92 \\
21.11 \\
8.79 \\
7.04 \\
4.02 \\
24.12\end{array}$ & 0.764 \\
\hline $\begin{array}{l}\text { Type of cancer } \\
\text { Breast } \\
\text { Lymphoma } \\
\text { Gynecological } \\
\text { Esophageal } \\
\text { Cervical } \\
\text { Stomach } \\
\text { Sarcoma } \\
\text { Head and neck } \\
\text { Lung } \\
\text { Ovarian } \\
\text { Thyroid } \\
\text { Other } \\
\text { Not specified }\end{array}$ & $\begin{array}{c}0 \\
9 \\
0 \\
4 \\
0 \\
4 \\
6 \\
6 \\
14 \\
0 \\
3 \\
42 \\
6\end{array}$ & $\begin{array}{c}0.00 \\
9.57 \\
0.00 \\
4.26 \\
0.00 \\
4.26 \\
6.38 \\
6.38 \\
14.89 \\
0.00 \\
3.19 \\
44.68 \\
6.38\end{array}$ & $\begin{array}{c}184 \\
17 \\
12 \\
2 \\
40 \\
7 \\
9 \\
10 \\
15 \\
19 \\
11 \\
32 \\
40\end{array}$ & $\begin{array}{c}46.23 \\
4.27 \\
3.02 \\
0.50 \\
10.05 \\
1.76 \\
2.26 \\
2.51 \\
3.77 \\
4.77 \\
2.76 \\
8.04 \\
10.05\end{array}$ & \\
\hline
\end{tabular}

Regarding the time elapsed since diagnosis, in $66 \%$ of cases it was one year or less, and in $12 \%$, more than five years had elapsed; in both genders, the highest percentages were observed in the less than one year or one year since diagnosis categories (Fig. 1).

The majority of patients were from Mexico City (34\%) or the State of Mexico (21\%).
The exploration of variables' behavior according to gender identified statistically significant differences in level of education ( $p=0.026$ ), affiliation $(p=0.000)$, time elapsed since diagnosis $(p=0.029)$ and age (established in four categories for the analysis) $(p=0.027)$, but not in relation to the place of origin. 


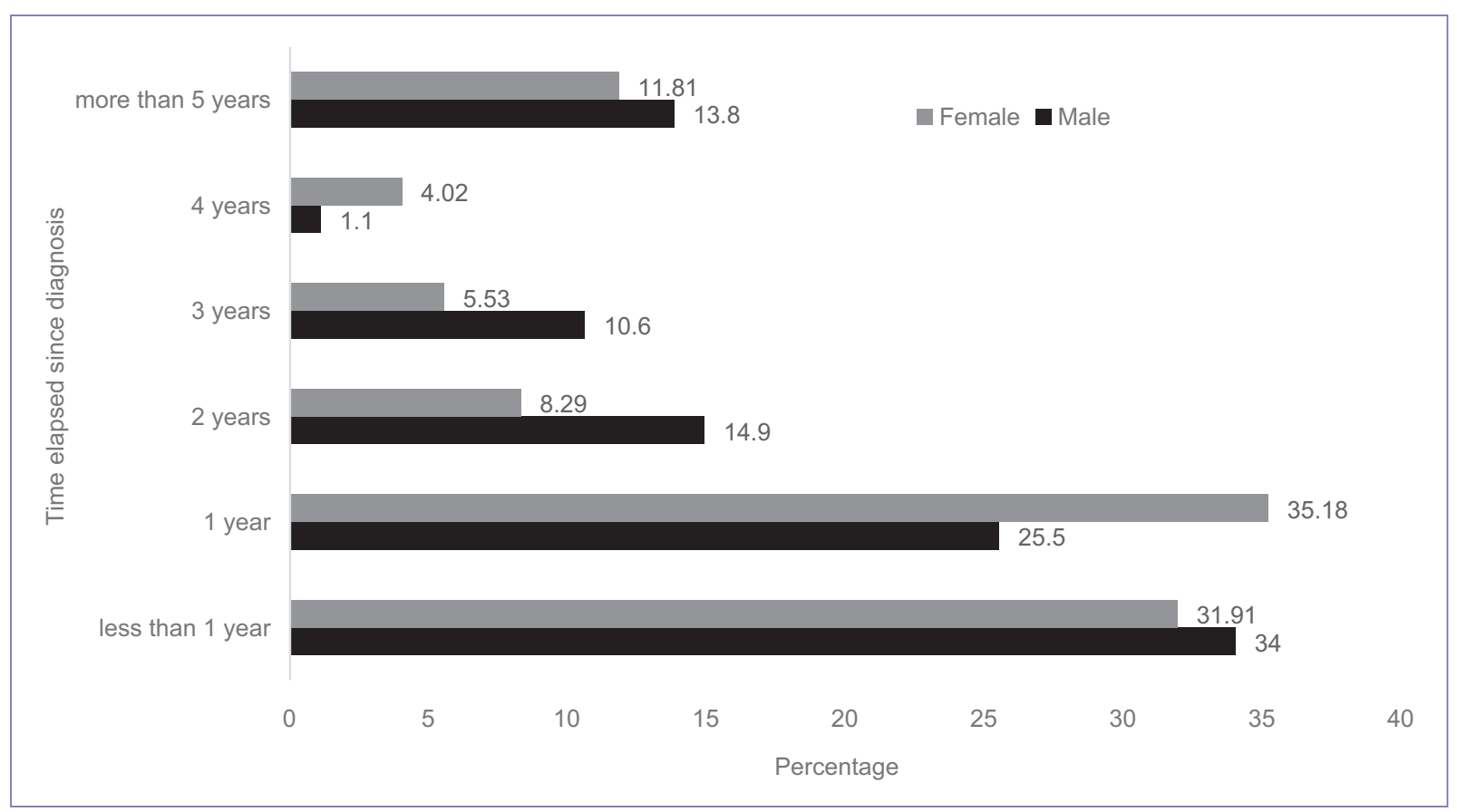

Figure 1. Percentage of patients who use complementary and alternative medicine (CAM) according to the time elapsed since diagnosis by gender.

Overall, the most commonly reported types of cancer were breast $(37 \%)$, cervical $(8 \%)$ and lung cancer $(5 \%)$. In women, breast cancer was the most common (46\%), and in men, lung cancer (15\%).

When the use of CAM was investigated, $80.3 \%(395)$ mentioned having used it and, out of these, $82.28 \%$ were women. However, no significant differences were observed between gender and CAM usage $(p=0.115)$.

The exploration by age group indicated that age was not associated with the use of CAM. However, it was more common in the group of 51-66 years (83), and it should be noted that, in subjects younger than 34 years, the use of CAM was higher than $80 \%$.

By type of cancer, women suffering from breast, cervical, ovarian and gynecological cancer and sarcomas have used CAM to a greater extent. All patients with esophageal cancer used CAM; however, there were only six subjects with this pathology.

According to affiliation status, participants with people's insurance are those who mainly use any type of CAM $(87 \%)$, with significant differences being found $(p=0.000)$ in comparison with patients with another type of health insurance affiliation. The analysis by level of education showed statistically significant differences $(p=0.000)$, with the highest percentages of CAM use being observed in the highest levels of education: high school, postgraduate and college education (95, 91 and 85\% respectively).
As for the time elapsed since diagnosis, those who have been spent four years with the disease are the patients who use CAM the most $(88 \%)$, whereas subjects who make less use of alternative medication are those who were diagnosed less than one year ago (76). (Fig. 1).

By CAM type, exercise and consumption of food supplements are the most widely used methods in the study population (39 and 37\% respectively). Herbal medicine and Mexican traditional medicine are also alternative methods used by a large proportion of patients (34 and $20 \%$ respectively) (Fig. 2).

According to the reason for use, $31 \%$ referred it was to feel better and $15 \%$ uses CAM to fight cancer; however, $9 \%$ of surveyed subjects gave no reason why they keep on using alternative medicine (Table 2).

Among the patients who specified the frequency of CAM use, $53 \%$ use it more than three times a week, $12 \%$ use it once a week, twice-weekly and occasional use have similar percentages (11\%), $8 \%$ of patients use it three times a week and only $4 \%$ once monthly.

For patients to start using any CAM, it was recommended mainly by a doctor (32\%) or a friend $(19 \%)$, $17 \%$ started with alternative medicine on their own initiative, $24 \%$ by family recommendation, $4 \%$ when receiving guidance at the Support Center for Comprehensive Care and an equivalent percentage by recommendation of any other person. 


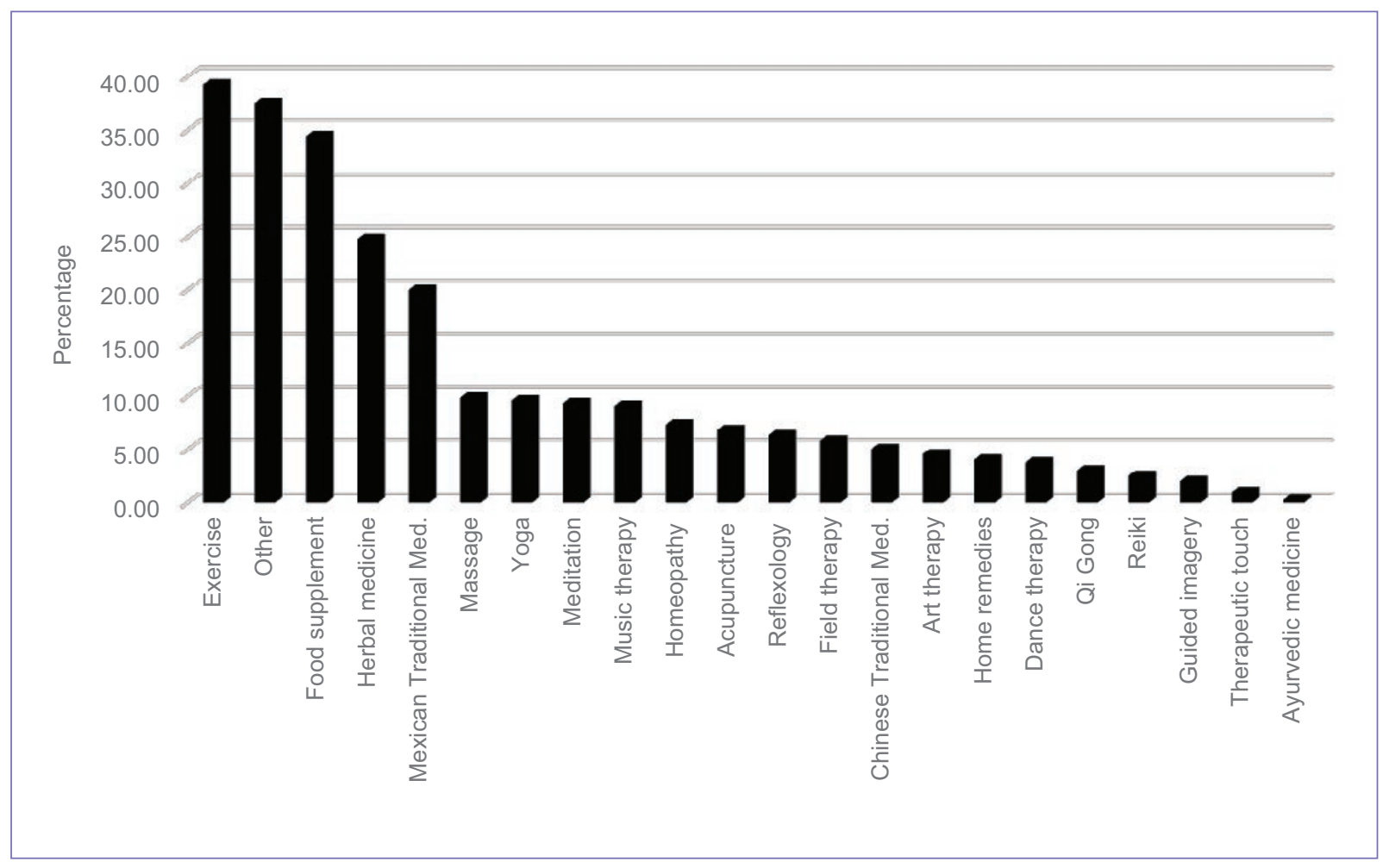

Figure 2. Frequency of complementary and alternative medicine (CAM) therapies use. Each one of the 395 patients who uses CAM mentioned the types of CAM he/she uses, from one to up 21 ( $n=395)$.

Table 2. Reasons for the use of complementary and alternative medicine

\begin{tabular}{|l|c|c|}
\hline Razones de uso & No. of subjects & $\%$ \\
\hline To feel better & 123 & 31.14 \\
\hline To fight cancer & 59 & 14.94 \\
\hline Symptomatology & 35 & 8.86 \\
\hline Immune system & 33 & 8.35 \\
\hline Appetite-anemia & 20 & 5.06 \\
\hline CT side effects & 19 & 4.81 \\
\hline To exercise & 14 & 3.54 \\
\hline Anxiety and stress & 13 & 3.29 \\
\hline Comorbidities & 10 & 2.53 \\
\hline Other & 32 & 8.10 \\
\hline Not specified & 37 & 9.37 \\
\hline Total & 395 & 100 \\
\hline
\end{tabular}

CT: chemotherapy.

In the logistic regression model, the level of education was identified to be significantly associated with the use of CAM; having completed secondary school, high school, college or postgraduate education increases the likelihood of using any unconventional treatment, with the highest association being observed when cancer patients have completed high school education (odds ratio [OR]: 27.11; 95\% confidence interval [CI]: 1.65-158.01). The type of cancer suffered by the patients showed statistically significant negative associations; specifically, being diagnosed with lymphoma (OR: $0.31 ; 95 \% \mathrm{Cl}: 0.10-0.94)$ or lung cancer (OR: 0.13 ; $95 \% \mathrm{Cl}: 0.05-0.36$ ) is related to using alternative medicine to a lesser extent (Table 3).

\section{Discussion}

CAM is appreciated for several reasons and is widely used in most countries of the world, and this consumption is rapidly increasing. For millions of people, this practice is currently the main source of health care and sometimes the only one. In addition, it is the closest to households, and it is accessible, affordable and culturally accepted; many of the people who use it fully rely on its efficacy and safety ${ }^{15}$.

The prevalence of CAM use in patients with cancer is often high, estimated at between 30 and $90 \%{ }^{16,17}$. 
Table 3. Variables associated with the use of complementary and alternative medicine

\begin{tabular}{|c|c|c|c|}
\hline Variable & Odds ratio & (95\% CI) & $\mathrm{p}<\mathrm{z}$ \\
\hline Gender & 0.84 & $(0.41-1.74)$ & 0.645 \\
\hline Age & 1.02 & $(0.99-1.04)$ & 0.114 \\
\hline $\begin{array}{l}\text { Time elapsed since } \\
\text { diagnosis } \\
1 \text { to } 2 \text { years } \\
3 \text { to } 4 \text { years } \\
5 \text { years or more }\end{array}$ & $\begin{array}{l}1.59 \\
1.29 \\
1.14\end{array}$ & $\begin{array}{l}(0.87-2.92) \\
(0.48-3.43) \\
(0.47-2.75)\end{array}$ & $\begin{array}{l}0.136 \\
0.613 \\
0.772\end{array}$ \\
\hline $\begin{array}{l}\text { Level of education } \\
\text { Primary } \\
\text { Secondary } \\
\text { High school } \\
\text { College and } \\
\text { postgraduate }\end{array}$ & $\begin{array}{c}1.28 \\
3.66 \\
27.11 \\
3.42\end{array}$ & $\begin{array}{c}(0.48-3.43) \\
(1.25-10.68) \\
(4.65-158.01) \\
(1.10-10.68)\end{array}$ & $\begin{array}{l}0.620 \\
0.018 \\
0.000 \\
0.034\end{array}$ \\
\hline $\begin{array}{l}\text { Type of cancer } \\
\text { Lymphoma } \\
\text { Cervical } \\
\text { Sarcoma } \\
\text { Head and neck } \\
\text { Lung } \\
\text { Ovarian } \\
\text { Other }\end{array}$ & $\begin{array}{l}0.31 \\
1.02 \\
0.24 \\
0.52 \\
0.13 \\
0.55 \\
0.33\end{array}$ & $\begin{array}{l}(0.10-0.94) \\
(0.34-3.06) \\
(0.40-1.40) \\
(0.12-2.22) \\
(0.05-0.36) \\
(0.16-1.90) \\
(0.16-0.69)\end{array}$ & $\begin{array}{l}0.039 \\
0.978 \\
0.112 \\
0.376 \\
0.000 \\
0.343 \\
0.003\end{array}$ \\
\hline
\end{tabular}

$\mathrm{Cl}$ : confidence interval.

Publications involving cancer patients from industrialized countries report it at between 25 and $84 \%{ }^{18}$. A recent meta-analysis that included 39 studies, reports that the proportion of cancer patients who used CAM at the time of the survey is between 9 and $88 \%$, and the combined proportion was $40 \%$ [95\% Cl: $33-47 \%]^{15}$. Considering the publications on Mexican population, a survey of pediatric cancer patients' relatives reported $70 \%$ of CAM use ${ }^{19}$ and another study involving patients with hematological malignancies in a hospital of northern Mexico reported a prevalence of $64.7 \%{ }^{20}$. In the present study, a prevalence of use of $80.3 \%$ was found, with this result being within previously published ranges. Differences in CAM intake according to gender have been found in some publications ${ }^{21-23}$, with a study conducted in Mexico in 2006 in patients with oncological disease in the private practice standing out. This study found the highest use of this type of therapies in young women with advanced disease, with the majority of CAM users being those who had been diagnosed with breast cancer $(88 \%)^{20}$. Similar results have been reported in cancer patients in Malaysia $(n=200)^{24}$, and in Scottish, Australian and North American women ${ }^{25-27}$. In this study, the difference in CAM intake according to gender and type of diagnosis is consistent with these findings, with intake being more common in women, in the age group of subjects younger than 34 and of 55 to 66 years of age and with breast cancer, although the differences were not statistically significant.

Regarding the level of education, the literature reports that patients with a higher level of education tend to use CAM more commonly $13,18,28$. In this sample of INCan cancer patients, a statistically significant association was found between CAM consumption and a level of education higher than primary school.

Regarding affiliation, solely determined by affiliation or not to the people's insurance, the majority of women with oncological disease were found to be affiliated, which is consistent with the inclusion of cervical and breast cancer in the Fund for the Protection against Catastrophic Expenses (FPGC - Fondo para la Protección contra Gastos Catastróficos) in 2004 and 2007. However, the proportion in men is lower, which is due to the fact that the year in which this study was conducted was the same year in which prostate cancer was included in the FPGC (2011). The time since diagnosis has been reported in some investigations as important in the decision to use CAM or not (statistical significance) ${ }^{13,17}$; however, no association was found in this study.

Contrary to our findings with regard to the type of cancer, where suffering from lymphoma is a negative factor, other studies have identified that patients with lymphoma use CAM the most $^{29}$, but data are consistent with the lung cancer diagnosis, given that relatively few patients with this diagnosis use any $\mathrm{CAM}^{21,30}$.

In our study population, $32.1 \%$ of subjects who use CAM do it by medical recommendation, which is a proportion close to that found in the literature $(<30 \%)^{17}$. In this work, health personnel recommended 7 of the 21 therapies used by INCan patients; the rest were used by suggestion of relatives, friends and neighbors or on patients' own initiative, among other reasons, just as reported in a 2015 study $^{31}$.

Regarding the reasons for CAM use, one of the most common in this population was to strengthen the immune system and to treat chemotherapy side effects, which were also documented in another study carried out with parents or caregivers of children with different types of malignant tumors ${ }^{16}$.

One factor that was not considered in this study was the investment made by patients for the use of CAM. In the literature, according to reports in the USA, the amount of money invested in CAM has been increasing in recent years; according to the results of the 2017 survey, North Americans spent USD \$ 33.9 billion on CAM therapies that year. Expenses are divided into natural products, instruction classes and materials, 
dietary supplements and the rest goes to visits to CAM practitioners such as acupuncturists, masseurs or chiropractors ${ }^{32}$.

It is necessary to expand the information on the use of complementary therapies, making an analysis of the cost-effectiveness and the cost the use of CAM represents for patients in Mexico.

It is important mentioning that non-conventional medicine is an important and often underestimated component of health services. It has been used for thousands of years by many cultures of different origins to preserve health, as well as to prevent and treat diseases, particularly chronic conditions ${ }^{6}$.

Currently, most cancer centers, including the INCan, have established integrative medicine programs to study and combine useful complementary therapies with conventional oncological care and also encourage the community of patients to be careful with the use of therapies that lack safety and efficacy data and that could be potentially harmful. Their purpose is to complement the treatment, the intervention and medical care, considering the individual as a psychosocial being. This implies that medical personnel must employ the best methods of a wide range in order to provide relief, making evidence-based decisions.

Currently, one of the great challenges faced by health institutions and the public, as well as by government areas involved in regulatory affairs, is related to the safety and efficacy, quality, availability, preservation and regulation of CAM. It is necessary for the health sector as a whole to identify and know the various alternative therapies used by this type of patients and their potential benefits and risks, in order to give better guidance on their use and establish therapies aimed at the benefit of the cancer patient, making the most of the whole range of existing treatments.

\section{References}

1. Stewart BW, Wild CP, editores. World Cancer Report 2014 [Internet] Lyon: International Agency for Research on Cancer [fecha de publicación: 2014]. Disponible en: https://www.drugsandalcohol.ie/28525/1/ World\%20Cancer\%20Report.pdf.

2. Cáncer. Datos y cifras [Internet]. Ginebra: Organización Mundial de la Salud [última actualización: 12 de septiembre de 2018]. Disponible en: http://www.who.int/mediacentre/factsheets/fs297/es

3. Estilos de vida más saludables, para prevenir el cáncer [Internet]. Ciudad de México: Secretaría de Salud, Publicaciones México Sano [fecha de publicación: 2015]. Disponible en: http://www.gob.mx/salud/documentos/ publicaciones-mexico-sano-2015

4. Gómez-Dantés H, Lamadrid-Figueroa H, Cahuana-Hurtado L, Silverman-Retana O, Montero P, González-Robledo MC, et al. The burden of cancer in Mexico 1990-2013. Rev Salud Publ Mex. 2016;58:118-31.

5. Valencia SC. Depresión en personas diagnosticadas con cáncer. Diversitas. 2006;2(2):241-57.

6. Managing Cancer-related Side Effects [Internet]. American Society of Clinical Oncology, Cancer.org [fecha de consulta: 12 de octubre de 2016]. Disponible en: http://www.cancer.org/treatment/treatmentsandsideeffects/physicalsideeffects/physical-side-effects-landing.
7. Complementary and Alternative Medicine [Internet]. Bethesda: National Cancer Institute [fecha última actualización: 10 de abril de 2015]. Disponible en: http://www.cancer.gov/about-cancer/treatment/cam

8. Medicina tradicional: definiciones [Internet]. Ginebra: Organización Mundial de la Salud [fecha de consulta: 15 de mayo de 2016]. Disponible en: http://www.who.int/topics/traditional_medicine/definitions/es/

9. Medicina tradicional [Internet]. Ginebra: Organización Mundial de la Salud [fecha de consulta: 15 de mayo de 2016]. Disponible en: http://www. who.int/topics/traditional_medicine/es/

10. Spadacio C, Barros de Felice N. Use of complementary and alternative medicine by cancer patients: systematic review. Rev Saude Publica. 2008;42(1):158-64.

11. Deng G, Frenkel M, Cohen L, Cassileth B, Abrams D, Capodice J, et al. Evidence-based clinical practice guidelines for integrative oncology: complementary therapies and botanicals. J Soc Integr Oncol. 2009:7(3):85-120.

12. Cirilo-Aguilar BG, Cantú-Martínez PC, Verde-Star MJ, Mata-Cárdenas B. Uso de la herbolaria en el cuidado de la salud. RESPYN Rev Salud Pública y Nutrición. 2011;12(2):Abril-Junio.

13. Lozaya X. La medicina tradicional en la realidad político-social de México [Internet]. México: Revista de Cultura Científica, Facultad de Ciencias, Universidad Nacional Autónoma de México [fecha de publicación: 1989]. Disponible en: http://www.revistaciencias.unam.mx/es/159-revistas/revista-ciencias-14/1377-la-medicina-tradicional-en-la-realidad-pol\%C3\%ADtico-social-de-m\%C3\%A9xico.html

14. Greenlee H, Balneaves LG, Carlson LE, Cohen M, Deng G, Hershman D, et al.; Society for Integrative Oncology. Clinical practice guidelines on the use of integrative therapies as supportive care in patients treated for breast cancer. J Natl Cancer Inst Monogr. 2014;50:346-58.

15. Organización Mundial de la Salud. Estrategia de la OMS sobre medicina tradicional 2014-2023. Ginebra: Ediciones de la OMS; 2013.

16. Klafke N, Eliott JA, Wittert GA, Olver N. Prevalence and predictors of complementary and alternative medicine (CAM) use by men in Australian cancer outpatient services. Ann Oncol. 2012;23(6):1571-8.

17. Horneber M, Bueschel G, Dennert G, Less D, Ritter E, Zwahlen M. How many cancer patients use complementary and alternative medicine: a systematic review and metaanalysis. Integr Cancer Ther. 2012;11(3):187-203.

18. Tascilar M, de Jong FA, Verweij J, Mathijssen RH. Complementary and alternative medicine during cancer treatment: beyond innocence. Oncologist. 2006;11(7):732-41.

19. Gomez-Martinez R, Tlacuilo-Parra A, Garibaldi-Covarrubias R. Use of complementary and alternative medicine in children with cancer in Occidental, Mexico. Pediatr Blood Cancer. 2007;49(6):820-3.

20. Jaime-Pérez JC, Chapa-Rodríguez A, Rodríguez-Martínez M, Colunga-Pedraza PR, Marfil-Rivera LJ, Gómez-Almaguer D. Use of complementary and alternative medicine by patients with hematological diseases: experience at a university hospital in northeast México. Rev Bras Hematol Hemoter. 2012;34(2):103-8.

21. Barnes PM, Bloom B, Nahin RL. Complementary and alternative medicine use among adults and children: United States, 2007. Natl Health Stat Report. 2008;10(12):1-23.

22. Molassiotis A, Fernandez-Ortega P, Pud D, Ozde G, Scott JA, Panteli V, et al. Use of complementary of alternative medicine in cancer patients: A European survey. Ann Oncol. 2005;16(4):655-63.

23. Gerson-Cwilich R, Serrano-Olvera A, Villalobos-Prieto A. Complementary and alternative medicine (CAM) in Mexican patients with cancer. Clin Transl Oncol. 2006;8(3):200-7.

24. Al-Naggar RA, Bobrychev $\mathrm{Y}$, Abdulgani M, Ramohan S, Osman MT Abdul SY. Complementary/Alternative Medicine use among cancer patients in Malaysia. World J Med Sci. 2013;8(2):157-64.

25. McLay JS, Stewart D, George J, Rore C, Heys SD. Complementary and alternative medicines use by Scottish women with breast cancer. What, why and the potential for drug interactions? Eur J Clin Pharmacol. 2012;68(5):811-19.

26. Kremser $T$, Evans A, Moores A, Luxford K, Begbie S, Bensoussan A, et al. Use of complementary therapies by Australian women with breast cancer. Breast. 2008;17(4):387-94.

27. Barnes PM, Powell-Griner E, McFann K, Nahin RL. Complementary and alternative medicine use among adults: United States, 2002. Adv Data. 2004;27(343):1-19.

28. Álvarez-Hernández E, Casasola-Vargas JC, Lino-Pérez L, Burgos-Vargas R, Vázquez-Mellado J. Frecuencia de uso de medicinas complementarias y alternativas en sujetos que acuden por primera vez al servicio de reumatología. Análisis de 800 casos. Reumatol Clin. 2006;2(4):183-9.

29. Downer SM, Cody MM, McCluskey P, Wilson PD, Arnott SJ, Lister TA et al. Pursuit and practice of complementary therapies by cancer patients receiving conventional treatment. BMJ. 1994;309(6947):86-9.

30. Molassiotis A, Panteli V, Patiraki E, Ozden G, Platin N, Madsen E, et al. Complementary and alternative medicine use in lung cancer patients in eight European countries. Complement Ther Clin Pract. 2006:12(1):34-9.

31. Sánchez R, Ibañez C, Suárez A. Utilización de terapias complementarias y alternativas en niños con cáncer. Rev Salud Pública. 2015;17(5):699-712.

32. Alternative medicine spending soars [Internet]. The Washington Post [fecha de publicación: 30 de julio de 2009]. Disponible en: http://voices.washingtonpost.com/checkup/2009/07/alternative_medicine_spending.html 